\title{
Ten Years of International Shipping on the Northern Sea Route: Trends and Challenges
}

\section{Björn Gunnarsson *}

Nord University, Centre for High North Logistics, Business School, Norway

\author{
Arild Moe \\ Fridtjof Nansen Institute, Norway
}

\begin{abstract}
Analysis of detailed statistics shows remarkable fluctuations in the volume and composition of voyages on the Northern Sea Route (NSR) along the northern coast of Russia since international use began in 2010. There has been strong growth in destination shipping between the Arctic and ports outside the region, but transit shipping between the Pacific and the Atlantic has not experienced the growth many had anticipated. Explanations are found in international market conditions as well as in the management of the NSR, with important lessons for the future development of different shipping segments. Shipping companies from several countries took part in the period up to 2019, but they seem to have become less central in the current phase of NSR shipping, which is dominated by the transport of hydrocarbons out of the Arctic. Russia expects international transit to pick up later. However, Russia alone cannot determine the volume of international traffic: it is the international shipping industry that will assess the balance of factors and conditions, and conclude if and when the shorter Arctic routes are safe, efficient, reliable, environmentally sound and economically viable in comparison with other routes.
\end{abstract}

Keywords: Arctic shipping, transit shipping, destination shipping, maritime transport, maritime logistics, North-East Passage, Russia, Arctic natural resources

Responsible Editor: Øyvind Ravna, Faculty of Law, UiT The Arctic University of Norway

Received: September 2020; Accepted: November 2020; Published: February 2021

\footnotetext{
^Correspondence to: Björn Gunnarsson, email: bjorn.gunnarsson@nord.no

(C) 2021 Björn Gunnarsson and Arild Moe. This is an Open Access article distributed under the terms of the Creative Commons Attribution-NonCommercial 4.0 International License (https://creativecommons.org/licenses/by-nc/4.0/), allowing third parties to share their work (copy, distribute, transmit) and to adapt it, under the condition that the authors are given credit, that the work is not used for commercial purposes, and that in the event of reuse or distribution, the terms of this license are made clear.

Citation: Björn Gunnarsson and Arild Moe. "Ten Years of International Shipping on the Northern Sea Route: Trends and Challenges" Arctic Review on Law and Politics,Vol. 12, 2021, pp. 4-30. http://dx.doi.org/10.23865/arctic.v12.2614
} 


\section{Introduction}

The Russian-governed Northern Sea Route (NSR) is the key section of the Northeast Passage between northwest Europe and northeast Asia. It has attracted growing international attention for several decades now, as the combination of diminishing ice cover and Russian interest in promoting traffic has created opportunities for foreign shipping companies in transit voyages between the Pacific and the Atlantic, as well as in the transportation of resources from the Arctic to world markets. This article will analyze the extent to which this sea route has become connected to the world economy over the last ten years, and what lessons can be drawn.

Most of the NSR research literature has focused on the use of the sea route for trans-Arctic transit between the Pacific and the Atlantic. The obvious advantages of using the NSR as a maritime trade route between ports in northwest Europe and northeast Asia are shorter transport distance $(30 \%-50 \%$ less) and reduced sailing time (14-20 days) compared to the Suez route, assuming the same sailing speed. Several studies over the past ten years have examined the economic viability of the NSR in comparison to the traditional Suez route, for different types of cargo. ${ }^{1} \mathrm{~A}$ few scholars have evaluated and assessed transit statistics on the NSR: Moe did so for 2011-2013; $;^{2}$ Humpert and Marchenko for $2013 ;{ }^{3}$ Lasserre and Alexeeva conducted a transit-trend analysis for both the NSR and the Canadian Northwest Passage for 2007-2012; ${ }^{4}$ and Zhang et al. analyzed transit data on the NSR combined with port call information from the Russian Arctic. ${ }^{5}$

However, there are also other aspects of international shipping on the NSR. Its role as a corridor to bring energy resources westwards to Europe and eastwards to Asian markets has come into focus in recent years with the rapid development of oil and LNG projects in West Siberia. ${ }^{6}$

Both transit shipping and destination shipping to foreign markets represent a connection between the sea route and the international economy, whether shipping operations are carried out by Russian or foreign companies. But international shipping companies' access to the NSR and their opportunity to offer shipping services constitutes a separate and third aspect of internationalization. In Soviet times the area was in practice closed for foreign vessels. After the turn of the century, many expected the NSR to become an interesting activity area for international shipping companies.

With these three aspects of internationalization in mind - international transits, destination shipping to foreign markets and access for international shipping companies the overarching research question in this article is: Does the development of shipping on the NSR represent increased internationalization in the use of the sea route?

Detailed statistics on NSR shipping spanning several years have not been available earlier. This has prevented in-depth analysis of the shipping activity which actually has occurred. This study presents the statistics now available and assesses what can be learned from ten years of international shipping on the NSR, 2010-2019. Moreover, we seek to identify the total volume of shipping over this period, the type of 


\section{Björn Gunnarsson and Arild Moe}

shipping that has taken place, and the dominant cargoes and nationalities involved. Finally, we want to discuss which factors have influenced these developments.

After a presentation of sources, methodology and definitions, the article provides a summary of the early history of shipping on the NSR. The article then analyses shipping activity on the sea route over the period 2010-2019 in detail. The discussion is organized chronologically into three periods characterized by unique shipping, trade, and economic conditions, as well as political developments. Finally, lessons learned are summed up and factors likely to influence the further development of shipping on the NSR discussed.

\section{Data Sources, Methodology \& Definitions}

NSR definition: Russian law defines the NSR as the water area along the northern coast of Russia. ${ }^{7}$ The NSR extends from the meridian of Cape Zhelaniya and along the east coast of the Novaya Zemlya Archipelago (the entrance to the Kara Sea), to the Line of Maritime Demarcation between Russia and the USA and Cape Dezhnev in the Bering Strait. The distance east to west is ca. 5,600 kilometers. The NSR water area extends to 200 nautical miles from the coast and includes Russian internal waters, the territorial sea, the adjacent zone, and the exclusive economic zone. Russia has established management and administrative systems for this area. Since ratification of the United Nations Convention on the Law of the Sea (UNCLOS) in 1997, Russia has maintained that its administration of the NSR is in line with UNCLOS Article 234, which provides the coastal state with extended rights to enforce regulations in ice-covered areas. In addition Russia maintains rights derived from developing the route: "Navigation in the area of the Northern Sea Route, a historically developed national transport communication of the Russian Federation, is carried out according to generally recognized principles and norms of international law, international treaties of the Russian Federation, ...," ${ }^{8}$ Russia's interpretation of these rights is disputed by some states, ${ }^{9}$ but is generally accepted by the international shipping industry. These legal issues are not discussed further here.

Data sources: The empirical data for this study come from four datasets: 1) statistics on the NSR 2010-2012 were provided by the Russian state nuclear icebreaker operator Atomflot in Murmansk; 2) official transit statistics 2013-2019 were provided by the Northern Sea Route Administration (NSRA) in Moscow; 3) statistics on all voyages on the NSR 2016-2019 came from the Centre for High North Logistics (CHNL) Information Office in Murmansk, which manages the CHNL's NSR Shipping Database based on Automatic Identification System (AIS) data provided by the Canadian satellite company exactEarth; 4) additional information on vessel characteristics and shipping companies/operators was found on marinetraffic.com. The study also benefitted from consultation with various shipping companies working on the NSR, including Atomflot. Internet sources were used to clarify the nature of various shipping activities: ship company websites, maritime newsletters, trade journals, and press releases. 
Methodology: Several types of data (variables) were extracted from the datasets to evaluate yearly variations in shipping on the NSR over the ten-year period. The vessel data allowed for a quantification of yearly changes in vessel characteristics, such as vessel type and ice class, as well as shipping companies operating the vessels. Similarly, yearly voyage data were used to quantify changes in cargo types and volumes, times and dates of voyages, and if icebreaker assistance had been required. These data also made it possible to distinguish between the three types of voyages based on origin and destination (O/D pairs; see definitions below) and the total number of cargo type and volume.

Voyage definitions: There is much confusion in the categorization of NSR shipping. In media reports numbers are cited, but the categories poorly defined, if defined at all. In particular, the term "transit" creates misunderstandings. In Russian reporting the term is used to denote any voyage that covers the major (eastern) stretch of the NSR, from the Ob Bay and eastwards. Such use of the term is logical when the focus is on the navigational aspects of shipping, as this is the part of the sea route that presents the main challenges. However, in western media, "transit" is usually understood as voyages between the Pacific and the Atlantic, which is of greater interest from an international commercial perspective. To clarify the different international aspects of NSR shipping, we apply these definitions:

- Voyage: If a ship leaves a port and arrives at another port (or in another water area, e.g. a research and supply vessel that does not call at a port) this is considered one voyage. If the same vessel departs from the first port visited and sails to another port, this counts as a second voyage.

- Voyage on the NSR: a voyage that originates from within the NSR, arrives in the NSR area, or transits the NSR. This definition is also used by the Russian authorities in assessing ship traffic and cargo volume on the NSR.

- Transit voyage on the NSR: when a vessel passes through both the western and eastern boundaries of the NSR without calling at ports en route.

- International transit voyage on the NSR: shipping between two non-Russian ports that passes through both the western and eastern boundaries of the NSR.

- Destination voyage on the NSR: Shipping between a Russian port and a nonRussian port. (A destination voyage can also be a transit voyage, e.g. from Murmansk to Yokohama. The two types are separated in the main text.)

- Domestic voyage on the NSR: Shipping between two Russian ports.

When we use the term International shipping on the NSR it cuts across these definitions of voyages. Our objective is to single out those parts of the shipping activity on the NSR that involve international shipping companies or foreign ports. Referring to the definitions above, this includes: a) international transit voyages between two non-Russian ports; b) destination voyages between a Russian port and a non-Russian port (in both of these categories voyages may be conducted by non-Russian or Russian companies); ${ }^{10}$ and c) domestic voyages on the NSR by non-Russian shipping companies. 


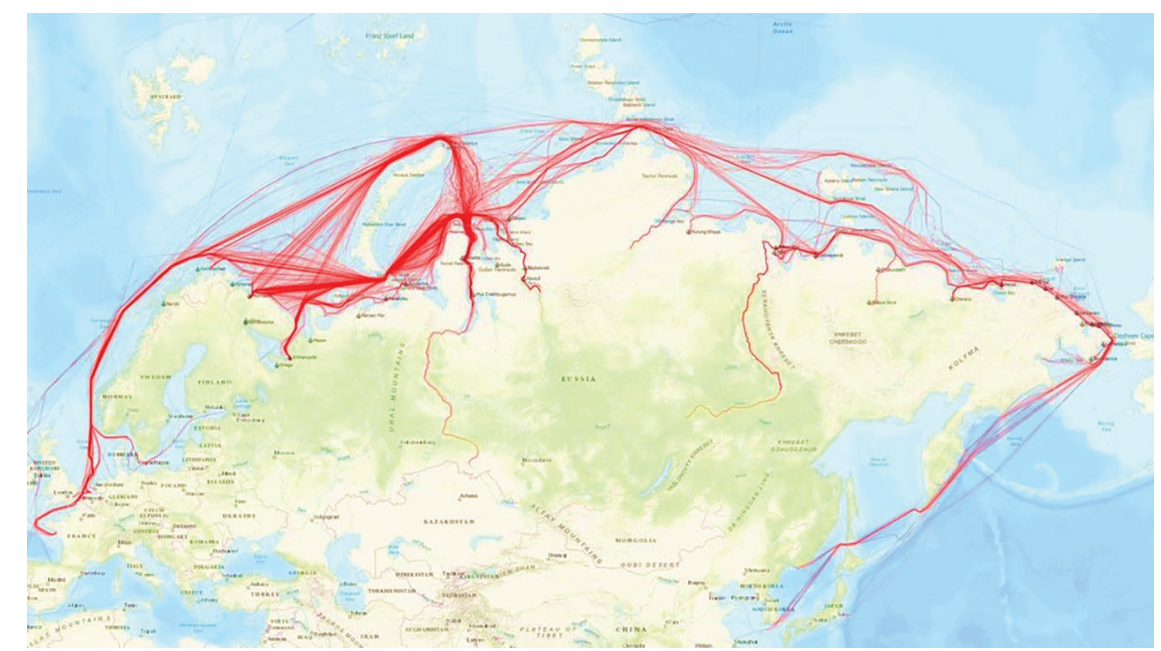

Figure 1. Sailing tracks of vessels operating on the NSR in 2018, based on AIS data: tracks of all domestic, destination, and international transit voyages on the NSR. Source: CHNL Information Office.

\section{Development of shipping on the NSR}

Since the early 1930s, the USSR/Russia has used the NSR as a regular shipping corridor for delivery of goods, supplies, fuel and equipment to remote localities and settlements on the Russian Arctic mainland and islands. ${ }^{11}$ This transport, known as "northern deliveries" and involving Russian inland waterways, took place during the late summer and early autumn when sea ice conditions were most favorable for shipping. The NSR was also used to transport raw materials, notably timber, coal and minerals from production sites near the coasts or rivers: the mining and metallurgical complex in Norilsk was the single most important cargo producer for the NSR. The Soviet nuclear icebreaker fleet was developed largely to escort traffic to and from Dudinka, the loading port for Norilsk, at the mouth of the Yenisei River. From 1978 this was done on a year-round basis, with non-ferrous metals being transported via the Kara Sea to Murmansk, and sometimes directly to European destinations. ${ }^{12}$

The NSR was officially opened for international shipping on January 1, 1991, following Mikhail Gorbachev's Murmansk speech in 1987, where he promoted international cooperation in the Arctic and mentioned shipping in particular. ${ }^{13}$ An international research project - the International Northern Sea Route Programme (INSROP) - was initiated by Russia between 1993-99 to explore conditions for extended use of the sea route. ${ }^{14}$ In connection with INSROP, a vessel from Norilsk Nickel's cargo fleet, Kandalaksha, undertook a demonstration voyage in August 1995 from Yokohama in Japan to Kirkenes in Norway. ${ }^{15}$ This was the first commercial international transit voyage on the NSR in modern times. Two years later, the Finnish-flag tanker Uikku of Neste Oil Shipping in Finland sailed from Murmansk eastwards along the NSR and through the Bering Strait into the Asian Pacific; after 
reloading in Asia, it sailed back to Murmansk, ${ }^{16}$ discharging fuel at several Russian Arctic ports along the NSR on its round-trip voyage. In 1997, the NSR authorities also reported that a Latvian-flag tanker had completed a transit of the route. ${ }^{17}$

However, the main conclusion of INSROP as regards commercial transit opportunities was that severe sea-ice conditions along the entire route during winter and spring made regular international commercial shipping technically and economically unviable. No international transit sailings took place in the following years. Then, in 2005 the Arctic Council published its Arctic Climate Impact Assessment (ACIA), noting the unprecedented changes to Arctic sea-ice cover and thickness as a result of global warming, ${ }^{18}$ and drawing attention to changed sailing conditions in the Arctic. Interest in commercial shipping on the NSR got a renewed boost in 2007 with reports of drastic reductions in the September minimum sea-ice coverage in the Arctic Ocean that year. ${ }^{19}$ These changes in Arctic sea ice prompted the Arctic Council to conduct its Arctic Shipping Assessment (AMSA), issued in 2009, highlighting several shipping scenarios due to sea-ice reduction with focus on enhancing Arctic marine safety and environmental protection. ${ }^{20}$

A new milestone for international shipping on the NSR came in 2009, when two heavy lift carriers, Beluga Fraternity and Beluga Foresight, belonging to the German company Beluga Shipping, delivered several heavy power-plant modules produced in South Korea to the port of Yamburg in the Ob Bay. ${ }^{21}$

\section{Analysis of Ten Years of International Shipping on the NSR: 2010-2019}

During the first ten years of regular transit shipping on the NSR, a total of 89 international transits and 68 destination voyages involving a foreign port took place, with international transit cargo volumes adding up to some 2.2 million tons (Table 1). The ten-year period also saw significant fluctuations in the composition of voyages.

Table 1. Transit voyages in international shipping on the NSR 2010-2019. Data sources: Atomflot (2010-2012) corrected for full transits only; NSRA (2013-2019); CHNL Information Office (2016-2019)

\begin{tabular}{ccccc}
\hline Year & $\begin{array}{c}\text { International } \\
\text { Transit }\end{array}$ & $\begin{array}{c}\text { International } \\
\text { Transit Cargo (t) }\end{array}$ & Destination Voyage & $\begin{array}{c}\text { Destination Voyage } \\
\text { Cargo }(\mathbf{t})\end{array}$ \\
\hline 2010 & 1 & 41000 & 1 & 70165 \\
2011 & 4 & 185243 & 14 & 590102 \\
2012 & 9 & 337371 & 17 & 793315 \\
2013 & 14 & 633791 & 14 & 484097 \\
2014 & 4 & 72472 & 2 & 0 \\
2015 & 6 & 34938 & 1 & 0 \\
2016 & 8 & 201946 & 5 & 0 \\
2017 & 12 & 154415 & 4 & 20253 \\
2018 & 17 & 339070 & 2 & 144499 \\
2019 & 14 & 285245 & 8 & 361094 \\
\hline Total & 89 & 2285491 & 68 & 2463525 \\
\hline
\end{tabular}




\section{Björn Gunnarsson and Arild Moe}

\subsection{International shipping on the NSR, 2010-2013}

The first international transit voyage by a non-Russian vessel transporting nonRussian cargo was the bulker Nordic Barents in September 2010, carrying iron ore from Kirkenes in Norway to Lianyungang in China. This voyage highlighted the potential savings for cargo and shipowners as a result of reductions in transport time, fuel consumption, and $\mathrm{CO}_{2} / \mathrm{NO}_{\mathrm{x}}$ emissions compared to the Suez route. ${ }^{22}$ This historic voyage was also used to promote partnerships in international shipping on the NSR. It was highly publicized that a Norwegian company was the cargo-owner; a Swiss-Russian trading company handled the logistics, with a Danish company as the shipowner and Russian companies providing icebreaker and navigational assistance. ${ }^{23}$

The years 2010-2013 were important for testing the technical feasibility of shipping on the NSR by Arc4 ice-class cargo vessels ${ }^{24}$ during the summer-autumn season with assistance from Atomflot's nuclear icebreakers. Many types of vessels (tankers, bulkers, LNG carriers, reefers, research vessels, icebreakers, and passenger vessels) and a range of ship sizes, with the 162,000 dwt Russian Suezmax tanker SCF Vladimir Tikhonov and Dynagas' chartered LNG carriers Ob River and Arctic Aurora of 100,240 GRT representing the largest, transited the NSR during this period, encountering varying sea-ice conditions and other weather-related operational conditions. These voyages provided shipping and insurance companies, flag states, classification societies and other stakeholders with information and data on vessels' operational conditions and speed in Arctic sea ice, and better ways of assessing the overall risk picture of shipping on the NSR.

The Russian authorities were a strong promotor of international commercial use of the NSR in these early years, as made clear in 2011 by Vladimir Putin, then Prime Minister: "We are planning to turn it into a key commercial route of global importance. I'd like to emphasize that we see its future as an international transport artery capable of competing with traditional sea routes in cost of services, safety and quality." ${ }^{25}$ The Russian government realized that if the country were to benefit from the increased international interest in Arctic shipping, it would need to improve the administrative and regulatory framework. More flexible conditions were introduced, first on a trial basis, with the first international voyages taking place in 2009 and 2010. New rules and regulations became permanent with a law that entered into force in 2013. ${ }^{26}$ Atomflot, the operator of the state-owned nuclear icebreaker fleet, seeking to attract foreign shipowners and cargo-owners, provided shipping companies with favorable icebreaker tariff rates (similar to Suez Canal fees per ton of cargo) and additional discounts based on cargo volumes and for in-ballast voyages. This approach resulted in several commercial transit voyages on the NSR, 2011-2013 (Table 1).

Altogether 28 international transit voyages took place during the first four years, 18 of them with cargo totaling 1.20 million tons. The cargo came from South Korea (jet fuel and gasoil: 556,000 tons, seven shipments), Norway (gas condensate, naphtha, 
LNG, iron ore: 437,086 tons, six shipments), Canada (coal: 145,286 tons, two shipments), China (general cargo: 58,313 tons, two shipments) and Vietnam (general cargo: 120 tons, one shipment). Most international transits were between northwest European ports and ports in northeast Asia, but there were notable exceptions, like ports in Thailand (Map Ta Phut), Taiwan (Mailiao) Vietnam (Tan Cang Cai Mep), Canada (Vancouver), USA (Nome), Aleutian Islands (Dutch Harbor), and Poland (Szczecin).

During this period, there were 46 destination voyages between ports in northwest Russia and ports in the Asian Pacific via the NSR, 35 of them with cargo of 1.94 million tons. Almost all cargo shipments went from the port of Murmansk - gas condensate was initially shipped from Vitino by the White Sea to Murmansk before onward shipment to the Asian Pacific. The only exceptions were three shipments from Ust-Luga (near St. Petersburg) and one from Larvik in southern Norway to Kholmsk in the Russian Far East. Two Russian companies provided the cargo: Novatek with gas condensate, Eurochem with iron ore. China received seventeen shipments (gas condensate: 431,407 tons, seven shipments; and iron ore: 575,496 tons, ten shipments), South Korea 12 shipments (gas condensate; 603,216 tons, ten shipments; and naphtha: 123,434 tons, 2 shipments) and other locations: Japan (naphtha), North Korea (general cargo), Singapore (heavy oil), Thailand (gas condensate), Malaysia (gas condensate) and Kholmsk (general cargo) with one shipment each, with a combined cargo volume of 204,126 tons.

In five cases tankers transported gas condensate or naphtha from Russia or Norway to Asia and jet fuel or gasoil from South Korea to Europe on the return voyage. But a large majority of the voyages were one-way shipments.

High commodity prices and demand in the Asian Pacific region justified paying higher transport costs by shipping these commodities to the Asian market, rather than to Europe. It was also shown that the overall cost savings of using the NSR instead of the Suez route depended on the type of cargo. A shorter shipping route for an expensive LNG carrier (time charter costs) meant substantial savings. ${ }^{27}$

One limitation on the use of the NSR as an international shipping route during this period was the availability of ice-strengthened vessels of different segments and sizes for use on Arctic voyages. Here Nordic shipping companies had an advantage over other shipping companies including many Russian companies. The former operated several 42,000 GRT and 74,000 dwt ice class A1 (Arc4) tankers, as well as bulkers in the Baltic Sea during the winter (Fig. 2, Fig. 3). Several of these vessels were used in international shipping on the NSR during the summer-autumn season. Thus, $49 \%$ of all voyages via the NSR 2010-2013 were made by Nordic shipping companies (Danish, Swedish, Finnish) or $64 \%$ if we exclude voyages involving Russian companies. At this time, shipping companies/operators from thirteen countries were participating in international shipping via the NSR (Fig. 4). 
2010-2013 $\square$ 2014-2015 $\square$ 2016-2019

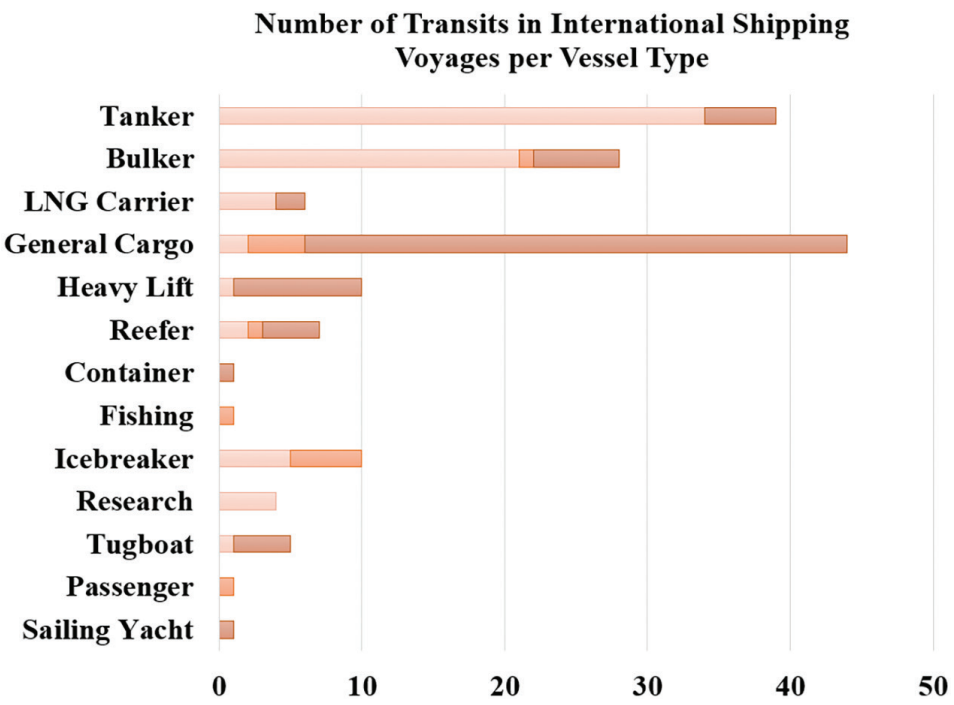

Figure 2. Transit voyages on the NSR by vessel type. Tankers and bulkers made the greatest number of voyages during 2010-2013, and general cargo vessels and heavy lift carriers during 2016-2019. Data sources: Atomflot (2010-2012) corrected for full transits only, NSRA (2013-2019), CHNL Information Office (2016-2019).

\section{0-2013 $\square$ 2014-2015 $\square$ 2016-2019}

\section{Number of Transits in International Shipping} Voyages per Range in Vessels' GRT

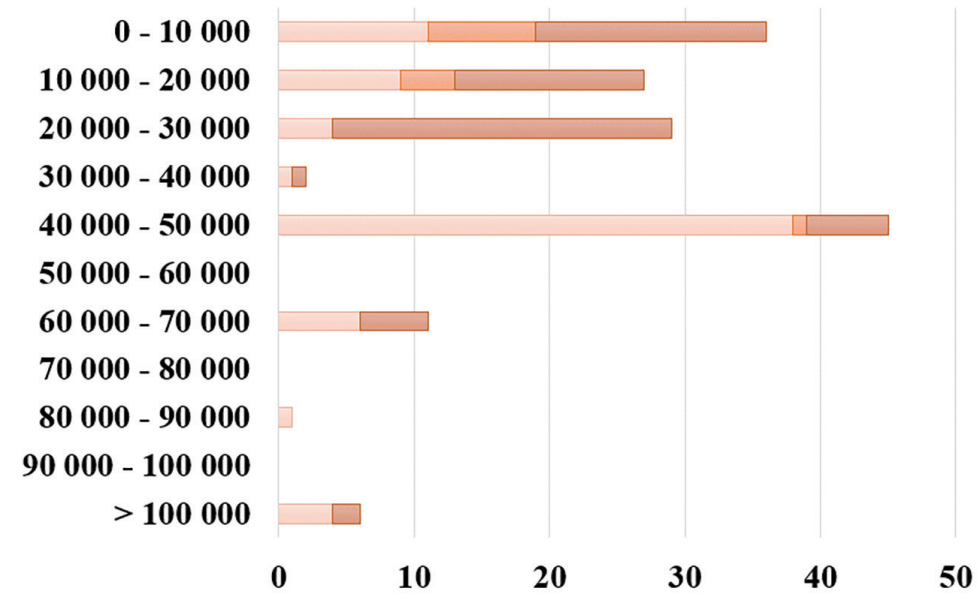

Figure 3. Transit voyages on the NSR per vessel gross tonnage (GRT). In 2010-2013 most voyages involved vessels in the 40,000-50,000 GRT range (tankers and bulkers); and 20,000-30,000 GRT in 2016-2019 (general cargo/heavy lift carriers). Data sources: Atomflot (2010-2012) corrected for full transits only, NSRA (2013-2019), CHNL Information Office (2016-2019). 
In this period, two Norilsk Nickel (now Nornickel) Arc7 container/multi-purpose vessels became the first cargo vessels to make round-trip voyages from a location within the NSR (Dudinka) to China (Shanghai): the Monchegorsk in 2010, and the Zapolyarniy in 2011. The vessels delivered nickel and copper metals to China, returning with consumer goods and equipment to the port of Dudinka. Nornickel has been shipping about 1.2 million tons of non-ferrous metals from Dudinka to Murmansk year-round on its own Arc7 vessels in addition to a few shipments of gas condensate. Some shipments have gone directly from Dudinka westwards to European destinations.

\section{0-2013 $\square$ 2014-2015 $\square$ 2016-2019}

\section{Number of Transits in International Shipping Nationality of Shipping Companies/Operators}

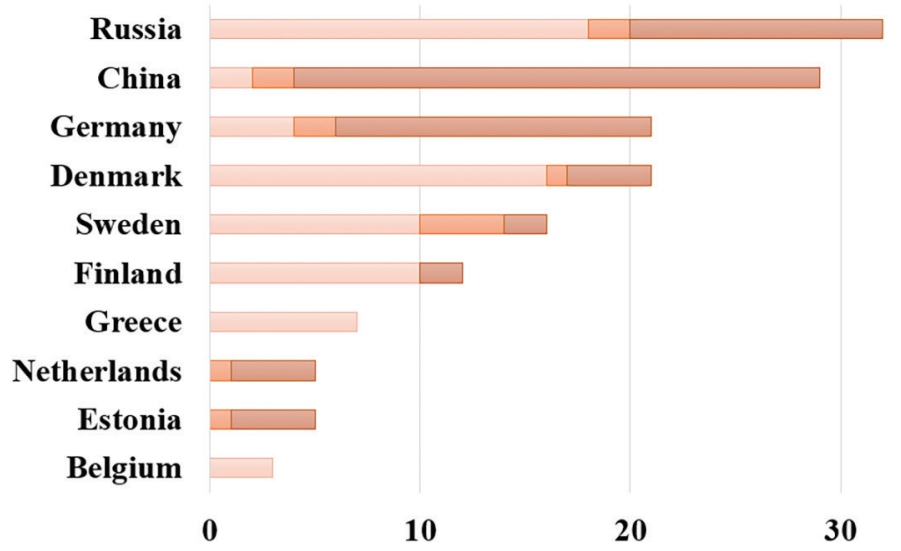

40

Figure 4. Transit voyages on the NSR by nationality of shipping companies/ship operators. Excluding Russian shipping companies, during 2010-2013 most of the vessels transiting the NSR were owned by Nordic companies (Danish: Nordic Bulk Carriers; Swedish: Marinvest; and Finnish: Neste Oil Company). Since 2016, transit voyages have been dominated by the Chinese COSCO Shipping, second by several German companies. Figure 4 shows only countries with three or more voyages. Data sources: Atomflot (2010-2012) corrected for full transits only, NSRA (2013-2019), CHNL Information Office (2016-2019).

\subsection{International shipping on the NSR, 2014-2015}

International shipping volumes on the NSR fell sharply in 2014-2015 (Table 1): ten international transits, with only five voyages carrying cargo, altogether 107,410 tons. Most of the cargo, 72,472 tons, was coal transported from Vancouver in Canada to Finland; the remainder was general cargo (33,000 tons) and frozen fish and meat (1,938 tons). There were only three destination voyages via the NSR, all of them relocations without cargo. What had changed that made the use of the NSR as a trade route so much less attractive? 


\section{Björn Gunnarsson and Arild Moe}

The main reason was probably difficult conditions on the freight market, starting in 2014 with the global economic downturn. Reduced bunker fuel prices at the start of the main navigational season made the NSR less attractive: lower fuel consumption and quicker sailing time compared to the Suez route now became less important as the overall cost of transportation became less significant for shipping operators and cargo-owners.

Commodity prices of raw materials fell sharply due to declining demand, especially in Asia. Freight rates were depressed as shipping companies struggled with overcapacity. The fall in commodity prices and even-out of previous price differences between European and Asian markets led to a decreased value-to-weight ratio of transported goods, and put corresponding emphasis on "economies of scale", making it more profitable to transport commodities on very large vessels going through Suez or around the Cape of Good Hope.

Partly because of freight-market conditions and reduced bunker-fuel prices, as well as the demand for their products, Novatek and Eurochem redirected their cargo away from the NSR in 2014, selling their products in Europe instead. This also, at least in the case of Novatek, had to do with the development of export terminal capacity in the Baltic Sea and a new processing plant at Ust-Luga near St. Petersburg. Regardless, the two main Russian cargo-owners that had spearheaded the international use of the NSR during 2010-2013 were now gone. This development sparked major uncertainties about cargo availability for transport on the NSR. There was only one international transit voyage with cargo in 2014: a shipment of coal from Vancouver in Canada to Finland by the Danish shipping company Nordic Bulk Carriers. The Chinese shipping company COSCO had used the NSR for the first time in 2013, transporting general cargo from NE Asia to Rotterdam in the Netherlands, with Chinese commentators touting the journey as the beginning of a major reshaping of international shipping. ${ }^{28}$ In 2015 COSCO had two international transit voyages with general cargo between Asia and Sweden.

The US/EU economic sanctions against Russia from 2014 after the Ukraine crisis, and the subsequent counter-sanctions from Russia, with ensuing geopolitical tensions and protectionism, did not encourage European shipping companies to get involved in NSR ventures that would require long-term investments in new vessels. Whether the new circumstances changed the motivation of "opportunistic" users who make decisions on route alternatives on a journey-by-journey basis is less certain, as such users would make a decision to use the NSR based on a review of current conditions.

Although transit traffic on the NSR had increased rapidly during 2010-2013 in relative terms, the absolute number of transiting vessels was still very low, with sailings only 4-5 months during the summer-autumn season. Despite Atomflot's heavy promotion of international shipping on the NSR, shipping companies and cargo-owners remained lukewarm. Far more transiting vessels would be required to make international transits a source of income for Atomflot. Moreover, limited 
information indicates that the icebreaker fees actually paid by international users were quite low - as low as 5 USD per ton, to match Suez Canal fees. Altogether, the development of international transit was disappointing.

In July 2012, construction of the new port in Sabetta on the eastern side of the Yamal Peninsula had begun, including extensive dredging operations. Year-round deliveries of construction materials, equipment, and supplies for the Sabetta port and the LNG plant required the assistance of nuclear icebreakers. Atomflot signed a long-term contract with the port of Sabetta and Yamal LNG to keep the sailing routes along the coast of the Yamal Peninsula open year-round. ${ }^{29}$ Atomflot was also contracted to assist Nornickel's vessels in difficult ice conditions during the winterspring season en route to and from the port of Dudinka on the Yenisei River, and year-round support in assisting tankers to and from Novy Port and the new Arctic Gate Terminal at Cape Kamenniy serving the Novy Port oil project in the southern part of the Yamal Peninsula. ${ }^{30}$

For international shipping companies it became clear that these and future Russian natural resource projects would increasingly occupy the capacity of Russia's nuclear icebreakers. Assistance to vessels on international transit voyages would become uncertain, with longer waiting time for icebreaker assistance and most likely higher escort fees. This hardly helped to promote international transit shipping on the NSR by non-Russian shipping companies.

\subsection{International shipping on the NSR, 2016-2019}

From 2016 to 2019 Russia focused on domestic and destination shipping on the NSR with project cargo related to development of its own energy and mining projects. This period saw a rapid increase in destination voyages. International transits increased in number compared to 2010-2013, but not in cargo volume. Non-Russian shipping companies were now also involved in domestic shipping on the NSR.

During the period there were 1,232 destination voyages on the NSR: 1,108 between the NSR and European ports, and 124 between the NSR and Asian ports (Fig. 5). The NSR port of origin/destination was almost exclusively Sabetta in the Ob Bay.

Russian companies were mainly involved in domestic shipping, transporting supplies, machinery and construction materials for infrastructure development in the $\mathrm{Ob}$ Bay, including construction of the port of Sabetta and the foundation for the Yamal LNG plant, as well as serving the Novy Port oil project further south on the peninsula. Most of these shipments originated from Murmansk and Arkhangelsk. In 2019 similar work started for construction of the Utrenniy terminal for the Arctic LNG-2 project on the Gydan Peninsula in the Ob Bay.

In 2016 the number of foreign shipping companies involved in domestic shipping on the NSR reached 23 with 90 voyages; in 2017 there were 22 companies with 92 
$\square 2016 \square 2017 \quad \square 2018 \square 2019$
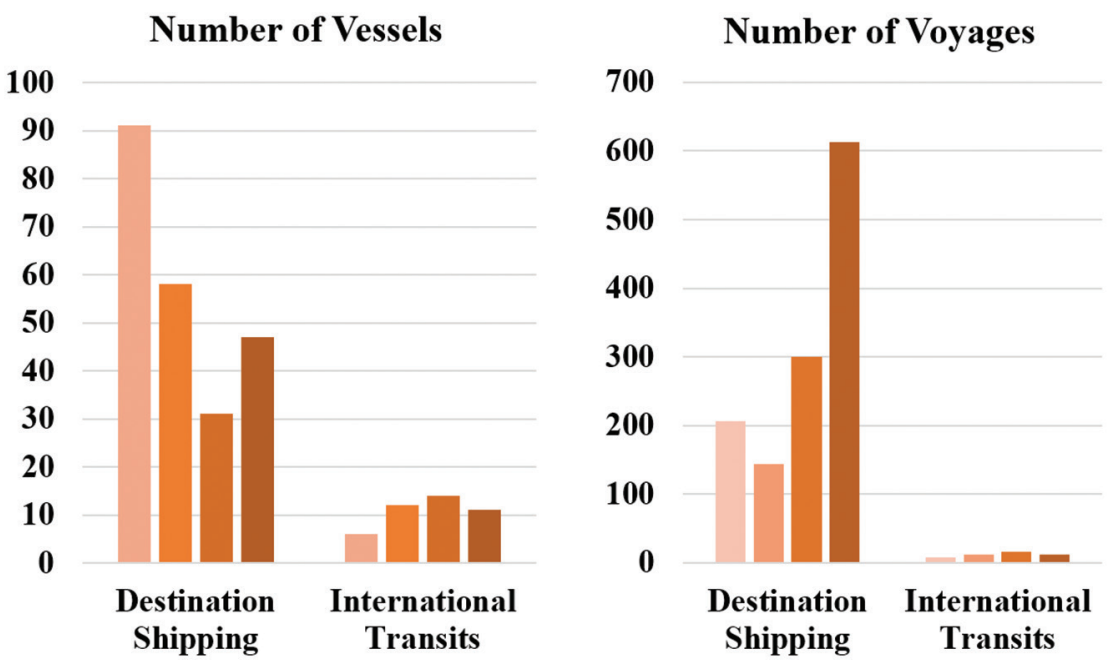

Figure 5. Number of vessels and voyages involved in destination shipping and international transit shipping on the NSR 2016-2019. Many vessels were involved in transporting project cargo to the port of Sabetta in 2016. The rapid increase in destination voyages in 2019 was the result of LNG and gas condensate shipments from the port of Sabetta to (mainly) European markets. Data sources: CHNL Information Office, NSRA.

voyages. Most of these voyages were between Murmansk and Sabetta (and locations offshore in the Kara Sea and in the Ob Bay). Several offshore support and supply vessels and tugboats were supplied by Norwegian companies; and dredgers, barges, and tugboats came from companies in the Netherlands, Luxembourg, and Belgium. Other non-Russian vessels in domestic shipping during 2016-2017 included general cargo vessels, bulkers, heavy lift carriers, LNG carriers (stopping in Murmansk before their first journey out of Sabetta), reefers, drilling rigs, a SAR (search and rescue) vessel, and a passenger vessel. Five domestic voyages (drilling rigs) were made by Chinese companies during this time.

Domestic voyages by non-Russian shipping companies dropped considerably in 2018 to 9 companies and 27 voyages, but rose in 2019 to 23 companies and 60 voyages. They included a few gas condensate tankers sailing from Sabetta to Murmansk, for onward shipment to Europe, and also LNG carriers stopping in Murmansk because of congestion at the trans-shipment facility at Honningsvåg, Norway (see below). In 2018-2019 Norwegian companies were involved in 26 offshore support voyages. Moreover, several Norwegian offshore support vessels were working in the Kara Sea for the Russian exploration company Marine Arctic Geological Expedition (MAGE). Additionally, four passenger vessels made fourteen domestic voyages in 2019. Asian companies had again only five voyages. 
European companies were also involved in transporting prefabricated LNG modules and other project cargo to the Yamal LNG plant at the port of Sabetta in 2016 and 2017 (mostly general cargo vessels and heavy lift carriers). These project shipments were completed in September 2017 (Fig. 6). The LNG modules originated from construction yards in China and Indonesia, and were shipped via the Suez route, first to Zeebrugge in Belgium and other European ports, before onward shipment to Sabetta. Several shipments also came through the Bering Strait during the summer-autumn season. Most of the European shipping companies transporting heavy project cargos to Sabetta were from the Netherlands (in 2016: six Dutch companies with 26 vessels, making 80 voyages to and from Sabetta), followed by companies from Germany (Fig. 7). Asian shipping companies were far less involved.

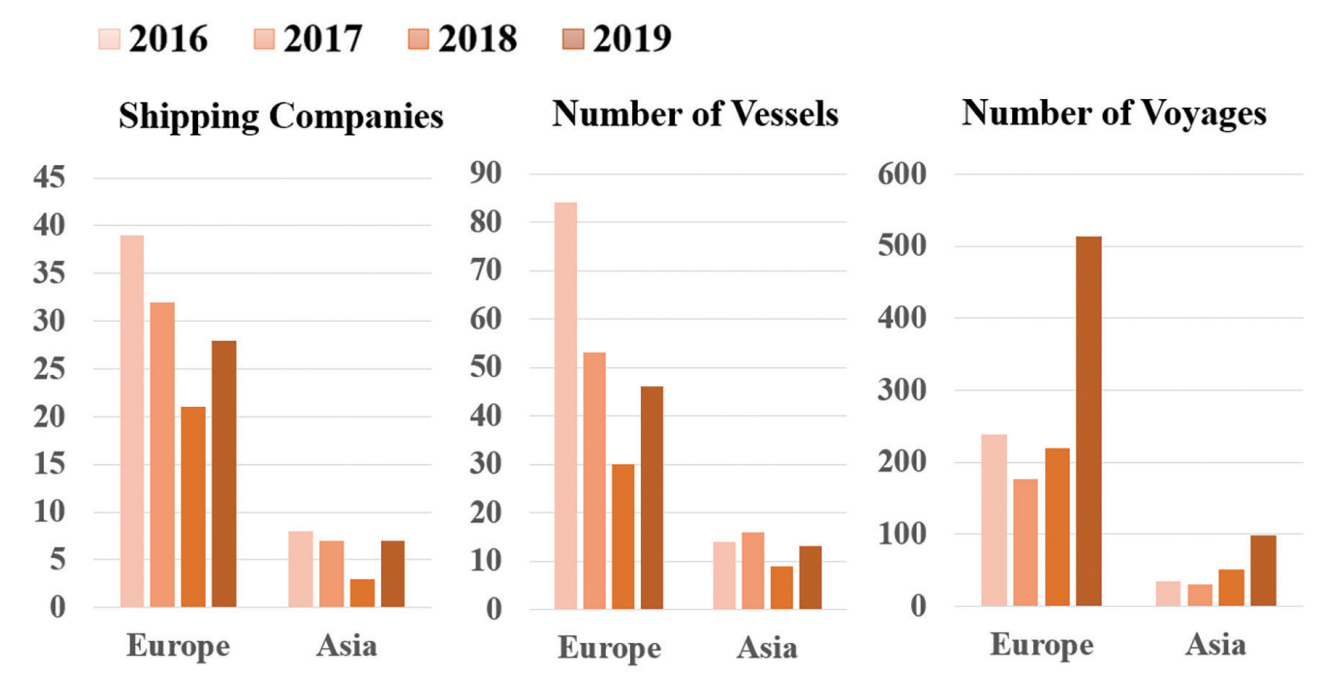

Figure 6. Number of European and Asian shipping companies/operators on the NSR in 20162019 and the number of their vessels and voyages on the NSR. Data sources: CHNL Information Office, and NSRA.

The first shipment from Yamal LNG took place in late December 2017. From 2018, shipments of LNG and gas condensate to western European ports for unloading or transshipment and return voyages back to Sabetta took off. Ship-to-ship transshipment of LNG from Arc7 icebreaking carriers to conventional carriers for further transport to western European ports started in November 2018 near Honningsvåg off the northern coast of Norway, lasting until the end of June 2019, with some voyages also occurring in 2020. ${ }^{31}$ Shipments of LNG eastbound to Asia started in 2018 with four shipments, increasing to twenty in 2019 in addition to one shipment of general cargo (likely of non-ferrous metals) from the port of Dudinka. In 2019, 254 shipments of LNG were brought from Sabetta by 23 LNG carriers to foreign markets, and 41 shipments of gas condensate by six tankers. 


\section{Björn Gunnarsson and Arild Moe}

Except for one LNG carrier owned and operated by Russia's Sovcomflot, these shipments of LNG and gas condensate from Sabetta were carried out by nonRussian companies on long-term charter contracts (Fig. 7). Three companies - from Greece (Dynagas), the UK (Teekay Shipping LNG) ${ }^{32}$ and Japan (Mitsui O.S.K. Lines) - made joint ventures with subsidiaries of China's COSCO Shipping for financing the construction of their new fleet of Arc7 LNG carriers, at some USD 300 million per vessel. Companies from Greece and Germany transported gas condensate from Sabetta (Fig. 7). Thus, it looked as if international shipping companies would have a strong role in the most dynamic segment of NSR shipping.

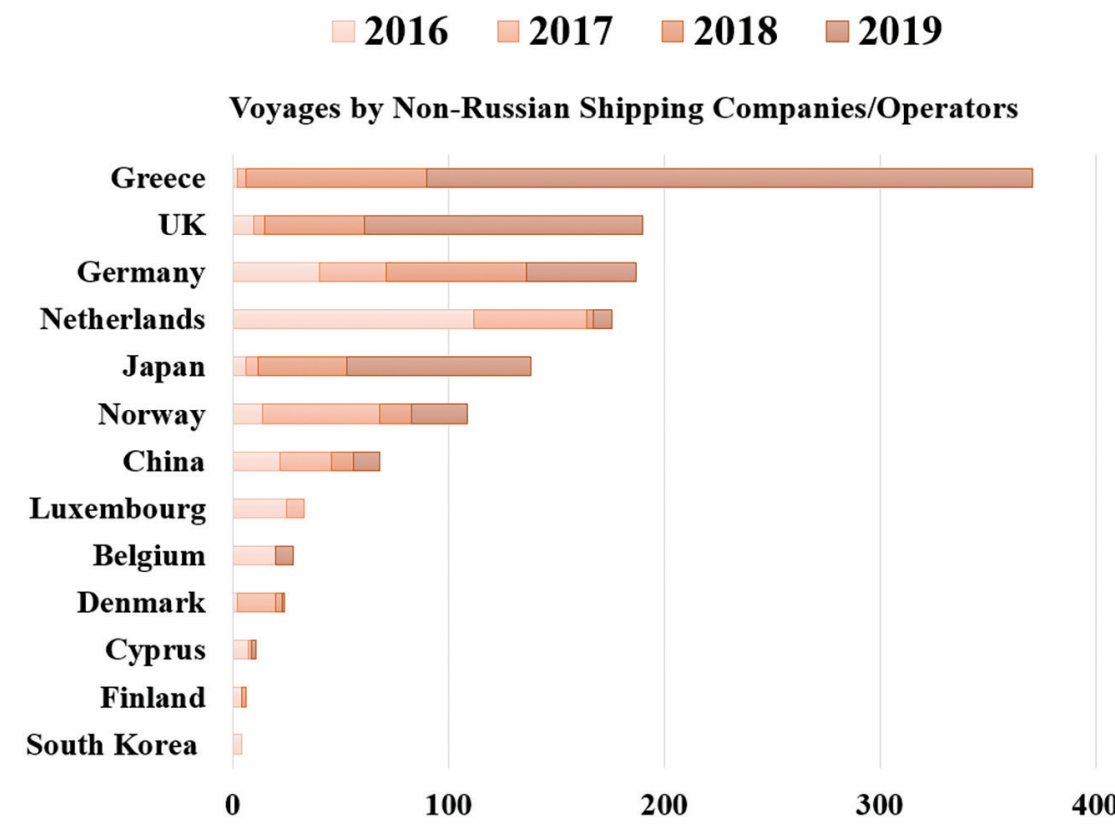

Figure 7. Nationality of foreign (non-Russian) shipping companies/operators working on the NSR, 2016-2019, and total number of their voyages during those years. Companies from Greece, UK and Japan were involved in regular transport of LNG from Sabetta. Norwegian companies were involved in offshore support. In addition, several Norwegian offshore support vessels were working in the Kara Sea in 2018 and 2019 for the Russian exploration company Marine Arctic Geological Expedition (MAGE). These voyages are not included in the figure. Data sources: CHNL Information Office and NSRA.

During 2016-2019 there were nineteen destination voyages via the NSR, twelve with cargo which added up to 525,846 tons (Table 1). The cargo consisted of general cargo, sawed timber, fertilizers, crude oil, and iron ore. In 2019, three Russian tankers delivered crude oil from Primorsk (near St. Petersburg) and Murmansk to China (302,151 tons). This was the first time since 2013 that Russian hydrocarbons had been shipped eastbound via the NSR to the Asian Pacific market from ports in NW Russia 
(Fig. 8). COSCO Shipping made two voyages with general cargo from Ust-Luga and St. Petersburg to China and Vietnam. Included here are also two shipments of iron ore from Mary River Mine on Baffin Island in Nunavut Canada (144,499 tons) to the arrival port of Nakhodka in the Russian Far East, though the final destination of the cargo was listed as being in Japan and Taiwan. There have been no deliveries of Russian iron ore eastbound on the NSR to the Asian Pacific region since 2013.

\section{Transits Destination}

\section{Number of Voyages to the Asian Pacific}

35

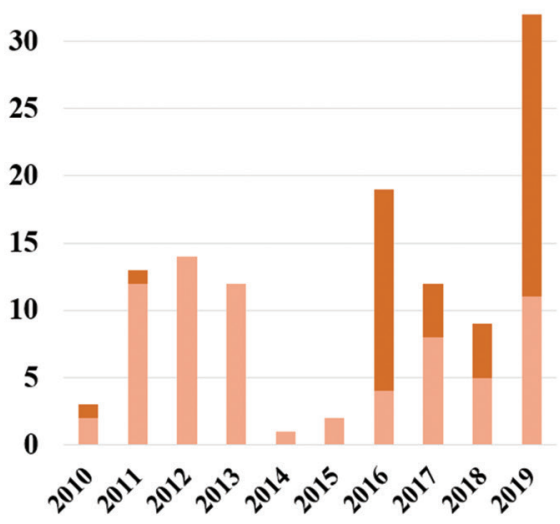

\section{Cargo Tonnage to the Asian Pacific}

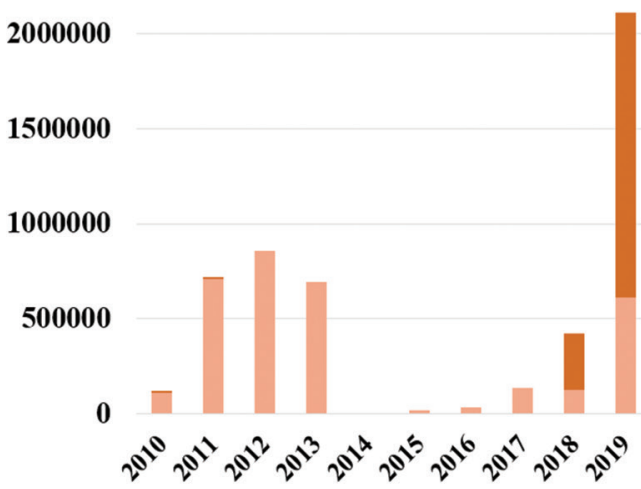

Figure 8. Number of voyages and cargo tonnage shipped from within the NSR (destination) or via the NSR (transits) to the Asian Pacific market, 2010-2019. The increase in 2019 was due to shipments of LNG. Data sources: Atomflot (2010-2012) corrected for full transits only; NSRA (2013-2019); and CHNL Information Office (2016-2019).

International transits also gained momentum (Table 1), but the playing field had changed. The tankers and bulkers that had characterized international shipping on the NSR were being replaced by lower tonnage general cargo vessels (including heavy lift carriers) transporting general cargo and project cargo, including wind power installations, between northeast Asia (China, South Korea, Japan) and northwest Europe (the five Nordic countries, Germany, the UK, the Netherlands, France). Most vessels were owned and operated by the Chinese COSCO Shipping Specialized Carriers company. COSCO made $45 \%$ of all international transits during this period, followed by German companies with $25 \%$.

There were 51 international transits in the 2016-2019 period, of which 47 voyages carried cargo totaling 980,676 tons (Table 1). Most of the cargo originated in Asia (28 voyages or $60 \%$ ) and primarily from China (nineteen voyages). A total of 29 voyages transported general cargo, four with paper pulp and five with frozen fish or meat. Four voyages originated in Canada (two with coal from Vancouver, two with iron ore from Baffin Island: 304,699 tons combined). 


\section{Björn Gunnarsson and Arild Moe}

Whereas international shipping 2010-2013 was characterized by the active participation of Nordic shipping companies, in 2014-2019 only Nordic Bulk Carriers (Denmark) was still involved, and with reduced activity. Its bulkers transported coal from Vancouver in Canada to Finland in 2014 (one voyage); anthracite coal from Dikson to Murmansk in 2017 (seven round-trip voyages); and iron ore from the Mary River Mine on Baffin Island, Canada, to Nakhodka in Russia in 2018 (two voyages) and to China in 2019 (one voyage).

\subsection{What has been learned from ten years of international use of the NSR?}

International use of the Northern Sea Route has increased over the past ten yearsbut not in the way and scope many had expected. Initially, we distinguished between three aspects of international use of the NSR: international transits, destination shipping to foreign markets and access for international shipping companies. Internationally, most attention has been given to transits between the Pacific and the Atlantic. This shipping activity has only seen modest growth and Arctic transits have not become a significant component in international shipping. Real growth has been in destination shipping between the Arctic and ports outside the region, conducted by Russian-owned as well as non-Russian vessels, to an extent hardly foreseen ten years ago. Shipping companies from many countries have been involved.

The past ten years have shown that the Arctic route is a relatively safe and reliable transit route for Arc4 ice class vessels for four months of the year, with August, September, October, and November offering the most favorable ice conditions. When regular transit shipping on the NSR began in 2010, all transiting vessels were required to have at least ice class Arc4 (A1) and were also required to seek assistance from a Russian icebreaker and take Russian ice pilots (ice navigators) onboard. Compulsory icebreaking escort and ice pilots were abolished from 2013, contingent on a decision by the Northern Sea Route Administration (NSRA). Since 2013, non-Arctic vessels with low ice classes (Ice1-3) have increasingly been allowed to transit the NSR (Fig. 9). Only one third or fewer transiting vessels have been assisted by icebreakers in recent years, according to the NSRA. This might seem to imply a higher operational risk, but no major accidents have occurred on the NSR in these years.

The participation of foreign shipping companies changed over the decade. Nordic shipping companies (Danish, Swedish, and Finnish) were heavily involved in transporting Russian gas condensate and iron ore to the Asian Pacific in 2011-2013, which had very much to do with the fact that they had ice-strengthened bulk ships available at a time when such cargoes were destined for Asian markets. China's COSCO Shipping has been most active in recent years in international transits, developing trade with other cargos, using general cargo and heavy lift carriers (Figure 2). This change underscores the fact that the cargo base is not a given and that new players may see new opportunities. The start of regular LNG and gas condensate shipments 


\section{Arc4+ $\square$ Ice1 $\square$ Ice2 $\square$ Ice3}

\section{Number of Voyages per Ice Class}

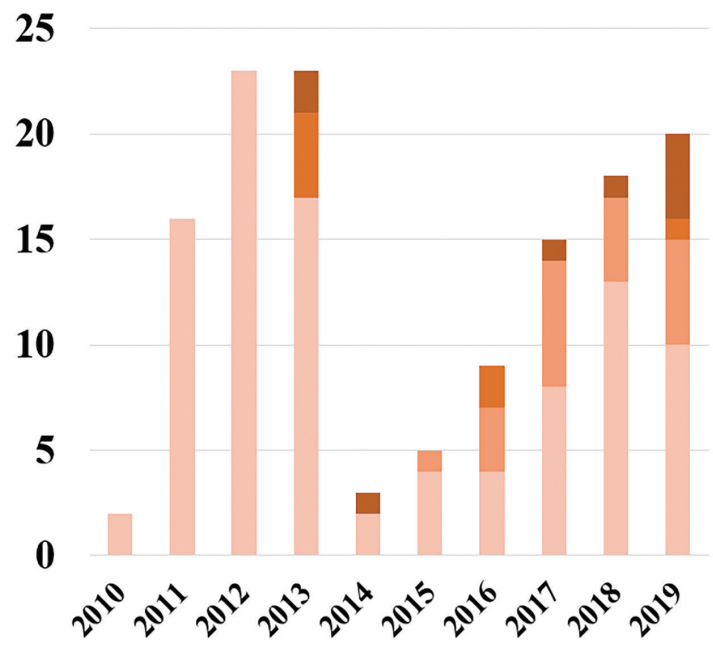

Figure 9. Transit voyages in international shipping per ice class on the NSR, 2010-2019. Only cargo and passenger vessels are included (no research or supply vessels, tugboats or icebreakers). Arc4+ means Arc4 and higher. In fact, higher occurred in only two cases for cargo vessels: one voyage in 2017 and one in 2019, in both cases by Arc7 LNG carriers. Data sources: Atomflot (2010-2012) corrected for full transits only; NSRA (2013-2019); and CHNL Information Office (2016-2019).

from Sabetta involved several leading international shipping companies as operators and partners.

Especially in the first years, many transit voyages had an experimental character, with ship and cargo-owners testing the technical feasibility of using the NSR for transits. This may have given an exaggerated impression of the lucrativeness of shipping on the sea route. In fact, international transit has been totally dominated by spot-market deliveries of commodities and transport of project cargo, and for vessel repositioning between the Atlantic and Pacific markets, all reflecting short term decisions by shipping companies and cargo owners and not long term strategies.

Developments in Russian administrative procedures and flexible fees on the NSR, first introduced on a preliminary basis in 2010 and permanently from 2013, against a background of receding ice have made transit more feasible and attractive than earlier. However, it has become increasingly clear that there are serious constraints on increased international transit shipping beyond Russian control. For container shipping seasonality is a serious economic obstacle. It means that the Arctic route cannot be used the whole year and that a separate logistical solution must be used when the NSR is not navigable. Unpredictability is also a deterring factor. Although sailings from the North Pacific to northern Europe is clearly shorter than 


\section{Björn Gunnarsson and Arild Moe}

the southern route, time spent will also depend on the ice situation, even in periods when it is not an absolute hindrance. Draft limitations mean that the biggest container ships - which today can be more than 20,000 TEUs (twenty-foot equivalent units) and provide economy of scale - cannot be used, except if they sail far north of the main NSR throughway into deeper waters where ice conditions are much more difficult. The absence of ports - and markets - underway limits the commercial potential. These are all factors seriously impacting the economics of container shipping on the NSR. In the years analyzed in this study, leading international container companies have shown scant interest in the NSR. Indeed, they have cited the factors listed above as arguments against using the NSR. ${ }^{33}$ No commercial traffic with large container ships has taken place. The widely reported journey by the new 3,600 TEU container ship Venta Maersk in August 2018 was mainly about repositioning from the shipyard in Asia to the Baltic Sea, but also a test of the practicalities of Arctic navigation. ${ }^{34}$ There is no sign that Maersk changed its skeptical attitude to Arctic container shipping.

Nevertheless, the limitations listed are not absolute barriers. Using general cargo/ multi-purpose vessels to transport different types of cargo, including high-value bulk and container cargo and time-sensitive project cargo (e.g. wind power equipment and machinery) could be a promising transport scenario for the NSR. COSCO Shipping has been developing plans for the transport of such goods between northeast Asia and northwest Europe since 2016. Such high-value cargo combinations could justify far higher transport fees for the shipper, even with relatively small volumes. Still, this is something different from large-scale international container shipping.

The natural constraints of NSR shipping do not apply to the same extent to bulk shipping, and in particular dry bulk shipping, which does not operate with justin-time deliveries and does not always need to work throughout the year. Thus, bulk transit shipping with ore, metals, chemicals and other solid raw materials between the Pacific and the Atlantic has been regarded as more promising for the NSR.

The main problem here is the absence of a sizeable cargo base. In world trade the main bulk cargo flows go north-south, and not between the North Pacific and the North Atlantic. ${ }^{35}$

Moreover, to justify investments in expensive ice class vessels, round-trip shipments with cargo between northeast Asia and northwest Europe in both directions would have to be the norm. Almost all voyages in the 2010-19 period were only oneway with cargo. In the most active transit period in terms of cargo tonnage, 20112013, only five tankers transported cargo in both directions on the NSR. Without backhaul cargos, the NSR will remain primarily a spot-market delivery route.

Even for spot-market deliveries, the relatively small size of vessels transiting the NSR with very limited cargo capacity compared to much larger vessels on the Suez route calls into question the commercial feasibility of such transport (see Fig. 3). During 2011-2013 high commodity prices in the Asian markets probably justified such a transport scheme - but that changed abruptly in 2014. This highlights the 
sensitivity of NSR transits for global market developments. If the price difference of commodities between the European and Asian markets is evened out, the rationale for sending such commodities through the Arctic disappears. By contrast, consistently high commodity prices (and high demand and prices in northeast Asia in particular) will be drivers of international transit shipping on the NSR.

A vital but often neglected factor in politically oriented studies of Arctic shipping is the freight market, which has decisively influenced the short-term use of the NSR as a trade route. The cost of chartering a vessel and the price of bunker fuel impacts the choice of route. When freight rates and bunker prices are low, any economic advantage of using the NSR compared to southern routes can be quickly lost, as occurred in 2014.

The drivers for destination shipping have been different. Here we see a concerted effort of Russian companies and government to develop huge resource projects with maritime logistics in the Arctic where there are no alternative modes of transport.

Experience shows that many factors directly related to the shipping business have affected the development of activity on the NSR in the past ten years. They will remain relevant, but their weight will differ in the commercial calculations of different shipping segments and for different cargo types.

\section{Looking Ahead: Determinants for International Shipping on the NSR}

The rapid growth in destination shipping in recent years has involved foreign shipping companies to a considerable extent. Maritime logistics, during the construction phase and for transporting resources out of the Arctic, is an integral element of large resource extraction projects. The pace of development is dependent, though, on the world energy markets. For international shipping companies these projects have offered promising opportunities.

Whereas the beginning of the period 2010-2019 was characterized by Russian efforts to involve the international shipping industry, recent developments have seen limitations on the future role of foreign shipping companies. The NSR is increasingly connected to the international economy through deliveries of energy, but new legislation in force from 1 February 2018 reserves this business for Russian-flagged vessels. ${ }^{36}$ Though foreign-flagged vessels on long-term contracts signed before this date (carriers for Yamal LNG and gas condensate) were excluded from this requirement, these regulations set the tone for Russia's increasing control of future shipping on the NSR involving its natural resources. Subsequent legislation has required that most carriers and tankers transporting hydrocarbons out of the NSR area must be built in Russia. ${ }^{37}$ These regulations did not directly impact shipping activities in the period under study here, since arrangements for existing projects were not altered, but they have major implications for further developments. It is conceivable that some foreign companies may circumvent the flag restrictions by re-registering their ships or chartering Russian flagged vessels. To our knowledge this has not yet 


\section{Björn Gunnarsson and Arild Moe}

happened, whereas the Russian authorities have granted exemptions from the flag requirement to thirteen existing conventional LNG carriers which will be employed in the Arctic. ${ }^{38}$ Permission to build some of the new Arc7 carriers abroad has also been given. ${ }^{39}$ Nevertheless, the impression is that foreign shipping companies will play a minor part in future destination shipping, compounded by plans to develop a Russian LNG shipping company, albeit with Chinese participation. ${ }^{40}$ The attention of the international shipping industry has therefore once again turned to international transits and the factors encouraging or discouraging the development of this activity.

Our review of factors affecting international transit traffic 2010-2019 applies mainly to short-term commercial calculations by shipping companies and cargoowners evaluating the use of NSR as a transit option. Companies contemplating investments in new tonnage to sail the Arctic route regularly will need to take broader political and economic framework conditions into consideration.

Here Russian policies and perceptions of Russian priorities will be extremely important. Obviously, having sufficient icebreaker capacity available to facilitate year-round navigation is essential, and Russia is intent on establishing such capacity. The reasoning in Russia is now that year-round passage through the NSR will be developed to serve transport of LNG to Asian markets. When this service is established towards the end of the 2020s, using the NSR for international transits can become a more attractive option. ${ }^{41}$

But the needs of users go beyond reliable icebreaker services. An effective and predictable administrative and management system serving international shipping is also required, including improved sea-ice predictions and ice reconnaissance, and acceptable fees. Given the long distances, well-equipped land-based and offshore emergency stations must be strategically placed along the whole length of the NSR, enabling timely response to all kinds of ship emergencies. Other necessary infrastructure improvements include the modernization of ports and better navigational infrastructure and hydrography, ice-navigation and communication systems..$^{42}$ Much is in the hands of Rosatom, the state atomic energy corporation, which since 2019 has served as infrastructure operator for the NSR, coordinating state investments, in addition to having responsibility for icebreaking by its subsidiary, Atomflot. ${ }^{43}$

These infrastructure needs are widely recognized in Russia, and official plans for improving the situation exist, most recently evidenced by the Plan for Development of the Infrastructure of the Northern Sea Route until 2035, adopted by the government on 21 December 2019. ${ }^{44}$ But many of the improvements are very costly. Russia has had great hopes of substantial Chinese investment in infrastructure, but the outlook remains uncertain. China's engagement thus far has been mainly confined to energy extraction projects and LNG carriers. ${ }^{45}$ Potential foreign users of the NSR will obviously monitor the development of infrastructure. Moreover, expectations and perceptions of Russian policies and plans will matter for investments in new tonnage. 
It is relevant to ask how important international transit is for Russia. When international transits began, many in Russia had exaggerated expectations both for the volumes of and income from such transits. Now the understanding is that icebreaker fees from transits will not be able to cover much of the infrastructure costs - and certainly cannot justify an expensive icebreaker construction program. But with the more recent, rapid development of extraction projects, responsibility for base financing has been turned over to these projects - albeit in combination with state subsidies or outright state investments. Transit income can bring in some extra revenues to help pay for infrastructure already established for and by the resource projects. There is still some expectation that transit will take off - but that it will come later. ${ }^{46}$

Various factors affecting international interest in transits on the NSR are outside Russian control. A basic precondition for transport between northwest Europe and northeast Asia is the existence of a sustainable cargo base. However, a sizeable permanent bulk cargo base between the two markets has not yet been identified. The prospects for international container shipping are even more uncertain. Container shipping has very high requirements as to predictability, which is a challenge for the NSR. Proposals for transshipment terminals located outside the eastern and western borders of the NSR are being studied. ${ }^{47}$ The actual Arctic transit would then be undertaken by specially designed ice-strengthened or icebreaking container ships (arctic shuttles), sailing only between the two transshipment terminals. Conventional feeder vessels would bring cargo to the terminals and deliver cargos from the terminals to their final destinations. The economics of such an arrangement remain uncertain. Rosatom has proposed that Russia should develop such an international container shipping business itself. ${ }^{48}$ But to achieve thriving container shipping in the Arctic, international participation will be essential.

Geopolitics also enters the picture: tensions, sanctions and countersanctions, higher trade tariffs and regionalization will not promote the development of international transit shipping via the NSR. Perceptions of increased militarization - real or imagined - along Russia's northern coast are also likely to hold back foreign investments.

Climate politics may play a role as well. Several big shipping companies and owners of international brands, concerned about projected environmental risks and impacts of Arctic shipping with ensuing reputational consequences, have already declared that they will not use the NSR or other Arctic routes. ${ }^{49}$ On the other hand, Russia can claim that shorter sailing distances using the NSR translate into reduced emissions. And if enough LNG-powered vessels are introduced, climate-related arguments in favor of the NSR will be strengthened. A scenario with ice-melt making it possible to sail outside the NSR boundary altogether is not imminent, but can emerge within the next few decades, at least for parts of the year..$^{50}$ This could have severe consequences for transits on the NSR, but Russia maintains that even under such circumstances Russian infrastructure will be needed for navigation and safety. 


\section{Björn Gunnarsson and Arild Moe}

For international transit shipping to develop, international market conditions and Russian policies must be conducive to such development. Russia cannot decide the potential for international transit shipping; on the other hand, positive international market developments and reduced tensions will not help if supportive policies and framework conditions are not in place. At the end of the day it is the global maritime industry - not only shipping companies and cargo-owners but also other stakeholders such as the marine insurance industry, ship classification societies, investors and shipbuilders - that will decide whether to use the NSR, for individual voyages or as a long-term option. They will assess the balance of factors and conditions, to judge if and when the shorter Arctic routes are safe, efficient, reliable, environmentally sound, and economically viable in comparison with other routes across the world's oceans. ${ }^{51}$ This will be a gradual process and different stakeholders may arrive at different conclusions, but all decisions involving major investments will require predictable conditions for the longer term.

\section{Acknowledgements}

The financial support by the Norwegian Ministry of Foreign Affairs' ARCTIC 2030 project NOR-15/0010 covering Gunnarsson's participation is greatly appreciated. Moe's contribution is part of the SIRAW project financed by the Research Council of Norway, grant no. 287576. Mr. Sergey Balmasov and his team at CHNL's Information Office in Murmansk, Russia is thanked for downloading of satellite AIS data from exactEarth and the management of CHNL's NSR Shipping Database since 2016. The authors are grateful to Lawson W. Brigham for useful comments to a draft of this article and to two anonymous reviewers.

\section{NOTES}

1. M. Furuichi and N. Otsuka, "Examining Quick Delivery at an Affordable Cost by NSR/ SCR-Combined Shipping in the Age of Mega-Ships," Maritime Policy E Management, 45 (2018): 1057-77, https://doi.org/10.1080/03088839.2018.1473656; T. Kiiski, "Feasibility of Commercial Cargo Shipping along the Northern Sea Route," PhD thesis, University of Turku, Finland (2017); J. F. J Pruyn, "Will the Northern Sea Route Ever be a Viable Alternative?” Maritime Policy \& Management 43 (2016): 661-75, https://doi.org/10.1080/030888 39.2015.1131864; C. Ø. Hansen, P. Grønsted, C. L. Graversen, and C. Hendriksen, “Arctic Shipping: Commercial Opportunities and Challenges," Copenhagen Business School (CBS) Maritime, (2016), Frederiksberg, Denmark; F. Lasserre, "Case Studies of Shipping along Arctic Routes: Analysis and Profitability Perspectives for the Container Sector," Transportation Research Part A, 66 (2014): 144-61, http://dx.doi.org/10.1016/j.tra.2014.05.005

2. A. Moe, “The Northern Sea Route: Smooth Sailing Ahead?" Strategic Analysis 38 (2014): 784-802, https://doi.org/10.1080/09700161.2014.952940

3. M. Humpert, "Briefing Note-Arctic Shipping: An Analysis of the 2013 Northern Sea Route Season," Arctic Yearbook 2014, eds. L. Heininen, H. Exner-Pirot \& J. Plouffe, https:// arcticyearbook.com/images/yearbook/2014/Briefing_Notes/1.Humpert.pdf; N. Marchenko, "Northern Sea Route: Modern State and Challenges," Proceedings of the ASME 33rd 
International Conference on Ocean, Offshore and Arctic Engineering (OMAE2014), June 8-13, San Francisco (2014).

4. F. Lasserre and O. Alexeeva, "Analysis of Maritime Transit Trends in the Arctic Passages," in: International Law and Politics of the Arctic Ocean, eds. S. Lalonde and T. McDorman, (Leiden: Brill Academic, 2015), 180-92, https://doi.org/10.1163/9789004284593_010.

5. Y. Zhang, Q. Meng, Q. and L. Zhang, "Is the Northern Sea Route Attractive to Shipping Companies? Some Insights from Recent Ship Traffic Data," Marine Policy 73 (2016): 53-60. https://dx.doi.org/10.1016/j.marpol.2016.07.030.

6. X. Li, N. Otsuka, and L. Brigham, "Spatial and temporal variations of recent shipping along the Northern Sea Route," Polar Science, August (2020), https://doi.org/10.1016/j. polar.2020.100569

7. Federal Law of July 28, 2012, N 132-FZ “On Amendments to Certain Legislative Acts of the Russian Federation Concerning State Regulation of Merchant Shipping on the Water Area of the Northern Sea Route.” http://www.nsra.ru/en/ofitsialnaya_informatsiya/zakon_o_ smp.html (accessed Sep. 14, 2020).

8. Ibid. Unofficial translation. See also Jan Jakub Solski, "New Developments in Russian Regulation of Navigation on the Northern Sea Route, Arctic Review, 4 (1) (2013). https://arcticreview.no/index.php/arctic/article/view/41; Viatcheslav V. Gavrilov, "Legal Status of the Northern Sea Route and Legislation of the Russian Federation: A Note," Ocean Development E International Law, 46:3 (2015), 256-263, DOI: 10.1080/00908320.2015.1054746.

9. Christopher R. Rossi, "The Northern Sea Route and the Seaward Extension of Uti Possidetis," Nordic fournal of International Law, Vol. 83 (4) (2014). https://doi.org/ 10.1163/15718107-08304004.

10. In this study the definition of a Russian shipping company is a company registered and headquartered in Russia and operating Russian-flagged vessels. This applies to the large majority of Russian shipping companies working on the NSR. In some cases, companies/operators with offices outside Russia and using foreign flag vessels on the NSR are subsidiaries of larger Russian shipping companies (e.g. Sovcomflot) and are here also counted as Russian companies/operators. The third category are a few foreign shipping companies with major subsidiaries registered in Russia (and often operating Russian-flagged vessels) managing all ship operations on the NSR.

11. W. Østreng, ed., The Natural and Societal Challenges of the Northern Sea Route: A Reference Work (Dordrecht: Kluwer Academic 1999), 20-26.

12. C. L. Ragner, "The Northern Sea Route: Commercial Potential, Economic Significance, and Infrastructure Requirements," Post-Soviet Geography and Economics 41 (2000): 541-80, https://doi.org/10.1080/10889388.2000.10641157548-549.

13. K. Åtland, "Mikhail Gorbachev, the Murmansk Initiative, and the Desecuritization of Interstate Relations in the Arctic," Cooperation and Conflict 43 (2008): 289-311. https://doi. org/10.1177/0010836708092838

14. INSROP, primarily a joint Norwegian-Japanese-Russian venture, enlisted more than 450 scholars in 14 countries and published 167 reports on aspects of the NSR in the period 1993-99, https://www.fni.no/projects/international-northern-sea-route-programme-insrop (accessed Sep. 14, 2020); Østreng 1999, op.cit.; Ragner 2000, op.cit.; R. D. Brubaker and C. L. Ragner, "A Review of the International Northern Sea Route Program (INSROP) 10 Years on", Polar Geography 33 (2010): 15-38. https://doi.org/10.1080/1088937X.2010. 493308

15. H. Yamaguchi "Experimental Voyage through Northern Sea Route," Proceedings of INSROP Symposium, Tokyo, Oct. 1-6 1995. https://www.researchgate.net/profile/Hajime_Yamaguchi2/publication/273767356_Experimental_Voyage_through_Northern_Sea_Route/ 


\section{Björn Gunnarsson and Arild Moe}

links/550bddf30cf290bdc1122b9f/Experimental-Voyage-through-Northern-Sea-Route.pdf (accessed Sep. 14, 2020).

16. Arctic Marine Shipping Assessment (AMSA), Arctic Council, Protection of the Arctic Marine Environment (PAME), 2009. https://pame.is/images/03_Projects/AMSA/AMSA_ 2009_report/AMSA_2009_Report_2nd_print.pdf (accessed Sep. 14, 2020).

17. Lawson W. Brigham, "The Northern Sea Route, 1997", Polar Record, 34, (190) (1998), 219-224.

18. Arctic Climate Impact Assessment (ACIA), Overview report, Cambridge University Press, (2005). www.amap.no/documents/doc/arctic-arctic-climate-impact-assessment/796 (accessed Sep. 14, 2020).

19. "Arctic Sea Ice Shatters All Previous Record Lows," Press release, National Snow and Ice Data Center (Boulder, CO), Oct. 1, 2007. https://nsidc.org/news/newsroom/2007_seaiceminimum/20071001_pressrelease.html (accessed Sep. 14, 2020).

20. AMSA, 2009, op. cit.

21. "Beluga Shipping Masters First Commercial Transit of the Northeast Passage," Power E Energy Solutions (n.d.), http://www.pes.eu.com/wind/beluga-shipping-masters-first-commercial-transit-of-the-northeast-passage/ (accessed Sep. 14, 2020).

22. “'MV Nordic Barents' makes historic voyage”, Barents Observer, August 26, 2010. https:// barentsobserver.com/en/sections/murmansk-obl/mv-nordic-barents-makes-historic-voyage (accessed Sep. 14, 2020).

23. "Historic Sea Route Opens Through the Arctic to China," Tschudi Shipping Company, 2010 http://www.tschudiarctic.com/page/208/Northern_Sea_Route_Project_2010 (accessed Sep. 14, 2020).

24. Russian Marine Register of Shipping (RMRS) ice classes are divided into non-Arctic, Arctic, and icebreaker classes. The ice-class notation is followed by a number denoting the level of ice strengthening: Ice 1-3 for non-Arctic ships; Arc4-9 for Arctic ships, and Icebreaker 6-9 for icebreakers.

25. "Prime Minister Vladimir Putin takes part in the second International Arctic Forum 'The Arctic - Territory of Dialogue,"” Arkhangelsk, September 22, 2011 (official translation). http://archive.premier.gov.ru/eng/events/news/16536/

26. J. J. Solski, "New Developments in Russian Regulation of Navigation on the Northern Sea Route".

27. Z. Raza and H. Schøyen, "The Commercial Potential for LNG Shipping between Europe and Asia via the Northern Sea Route," fournal of Maritime Research 11 (2014): 67-79. https://www.jmr.unican.es/index.php/jmr/article/view/290/309.

28. A. Moe, and O. S. Stokke, "Asian Countries and Arctic Shipping: Policies, Interests and Footprints on Governance," Arctic Review, 10 (2019): 24-52, https://doi.org/10.23865/arctic.v10.1374

29. O. Plotonova and S. Romanova, “Сабетта: песнь газа, льда и атома” [Sabetta: A song about gas, ice and the atom], Atomny Ekspert, 8, 2016. https://atomicexpert.com/page401980.html (accessed Sep. 16, 2020).

30. S. A. Golovinskiy, “Деятельность «Атомфлота» на Севморпути и перспективы её развития” [Atomflot's activity on the Northern Sea Route and perspectives for its development], ProAtom, Sep. 30, 2015. https://www.proatom.ru/modules.php?name $=$ News\&file $=$ article\&sid $=$ 6268 (accessed Sep. 16, 2020). Atomflot had an uneasy relationship with Norilsk Nickel since 2008 when the mining company decided to terminate its existing contract with Atomflot, instead relying on its own fleet of high ice class cargo vessels.

31. "Yamal LNG is on its way back to Norway," Barents Observer, March 29, 2020. https:// thebarentsobserver.com/en/industry-and-energy/2020/03/yamal-lng-its-way-back-norway (accessed Sep. 14, 2020). 
32. Teekay Shipping is here listed as a UK company, but the headquarters are in the Bahamas and the company is usually considered a Canadian company. LNG operations are, however, run from the UK.

33. Taedong Lee and Hyun Jung Kim, "Barriers of Voyaging on the Northern Sea Route: A Perspective from Shipping Companies," Marine Policy, 62 (2015).

34. "Maersk launches container ship on Arctic route," Financial Times, August 21, 2018. https:// www.ft.com/content/fb38b6ac-a484-11e8-8ecf-a7ae1beff35b

35. H. Falck, "Arctic Shipping Perspective in the Context of Global Shipping", in Robert W. Corell et al. (eds.) The Arctic in World Affairs: A North Pacific Dialogue on Arctic 2030 and beyond: Pathways to the Future, 2018 North Pacific Arctic Conference Proceedings, Busan, Republic of Korea: Korea Maritime Institute; Honolulu, Hawaii: East-West Center, 2018, 248-262. https://www.eastwestcenter.org/publications/the-arctic-in-world-affairsnorth-pacific-dialogue-arctic-2030-and-beyond-pathways-the

36. A. Moe, "A new Russian policy for the Northern sea route? State interests, key stakeholders and economic opportunities in changing times," The Polar fournal, (2020) DOI:10.1080/21 54896X.2020.1799611.

37. Ibid.

38. Распоряжение Правительства Российской Федерации [Executive order of the Government of the Russian Federation] November 14, 2019, No 435-r. http:/government.ru/docs/ all/120969/

39. “Новатэк сможет заказать газовозы за рубежом” [Novatek may order gas carriers abroad], Kommersant, January 23, 2020. https://www.kommersant.ru/doc/4227604

40. "NOVATEK, COSCO SHIPPING, Sovcomflot and Silk Road Fund Sign an Agreement in Respect of Maritime Arctic Transport LLC”, Press release from Novatek, June 7, 2019. http://www.novatek.ru/en/press/releases/index.php?id_4=3243

41. "Вячеслав Рукша: Росатом должен обеспечить российские мегапроекты в Арктике" [Vyacheslav Ruksha; 'Rosatom shall ensure Russian mega-projects in the Arctic'], Rosatom (original source Novosti), April 9, 2019. https://www.rosatom.ru/journalist/interview/ vyacheslav-ruksha-rosatom-dolzhen-obespechit-rossiyskie-megaproekty-v-arktike/?sphrase_ id $=840187$ (accessed Sep. 14, 2020).

42. B. Gunnarsson, "The Future of Arctic Marine Operations and Shipping Logistics" In: The Arctic in World Affairs, A North Pacific Dialogue on the Future of the Arctic, 2013: North Pacific Arctic Conference Proceedings, eds. Oran R. Young, Jong Deog Kim and Yoon Hyung Kim (Seoul and Honolulu: Korea Maritime Institute and East-West Center): 37-61. www.eastwestcenter.org/sites/default/files/filemanager/pubs/pdfs/Arctic2013/2013arctic-03shipping. pdf (accessed Sep. 14, 2020).

43. Moe, "A new Russian policy for the Northern sea route?"

44. План развития инфраструктуры Северного морского пути на период до 2035 года [Plan for development of the infrastructure of the Northern Sea Route]. Executive order of the Government of the Russian Federation No. 3120-r. December 21, 2019. http://government.ru/ docs $/ 38714 /$ (accessed Sep. 14, 2020).

45. Moe and Stokke, "Asian Countries and Arctic Shipping: Policies, Interests and Footprints on Governance".

46. Recent Russian policy developments and outlook are discussed in Moe, "A new Russian policy for the Northern sea route?"

47. Gunnarsson, "The Future of Arctic Marine Operations and Shipping Logistics".

48. “Росатом' хочет стать мировым лидером морских перевозок," [Rosatom wants to become a world leader in maritime transport] Vedomosti, Nov. 20, 2019. https://www.vedomosti.ru/ business/articles/2019/11/20/816799-rosatom-liderom (accessed Sept. 14, 2020). 


\section{Björn Gunnarsson and Arild Moe}

49. "Nike, other retailers vow not to use Arctic shipping routes," Arctic Today, October 31, 2019. https://www.arctictoday.com/nike-other-retailers-vow-not-to-use-arctic-shipping-routes/ (accessed Sept. 14, 2020).

50. M. Bennett, S. Stephenson, K. Yang, M. Bravo, B. DeJong, "The opening of the Transpolar Sea Route: Logistical, geopolitical, environmental, and socioeconomic impacts," Marine Policy, August (2020). https://doi.org/10.1016/j.marpol.2020.104178.

51. B. Gunnarsson, "Future Development of the Northern Sea Route," Maritime Executive, February 18, 2016. https://www.maritime-executive.com/editorials/future-development-ofthe-northern-sea-route (accessed Sep. 14, 2020). 